\section{Stefanovych T.,} Shcherbovskykh $\mathbf{5}$.

\title{
ACCOUNTING OF SWITCHING DEVICE ERRORS FOR SYSTEM WITH SLIDING REDUNDANCY BASED ON DYNAMIC FAULT TREE
}

Об’єктом дослідження є невідновлювана система з однократним ковзним резервуванням. Така система складається із двох основних підсистем, однієї резервної та двох перемикальних пристроїв. Поки обидві основні підсистеми пращездатні, резервна підсистема перебуває у ненавантаженому стані. Резервна система призначена для заміни будь-якої основної підсистеми після ї відмови. Перемикальні пристрої комутують основні підсистеми із резервною. В ході аудиту виявлено, що перемикальні пристрої допускають помилки. Зокрема помилку першого роду, тобто перемикаються завчасно, та помилку другого роду, тобто пропускають момент перемикання. Це знижує надійність системи та веде до недовикористання закладеного в неї ресурсу.

Запропоновано підхід, який кількісно враховує вплив помилок першого та другого роду на ймовірність безвідмовної роботи досліджуваної системи під час ї проектування. Підхід складається з двох етапів. На першому етапі надійність системи математично описується динамічним деревом відмов. На другому етапі на основі дерева відмов формується марковська модель. Застосовуючи ї, можна обчислити ймовірнісні характеристики системи.

Отриманим результатом є математична залежність між ймовірністю безвідмовної роботи системи та параметрами елементів системи. Зокрема, параметрами напрацювання до відмови основних та резервних підсистем, а також параметрами перемикальних пристроїв, які відповідають помилкам першого та другого роду. Формою представлення отриманих результатів для кінцевого користувача є програмний продукт, який автоматизовано генерує сімейство графіків для оиінювання надійності. Ігнорування помилок перемикальних пристроїв під час проектування систем знижує їх фактичну надійність, призводить до недовикористання ресурсів резервних елементів, а також збільшує ймовірність аварійних ситуацій.

Використання більш точної математичної моделі дає можливість контролювати помилки перемикальних пристроїв під час проектування системи. Результати моделювання будуть корисні для вибору параметрів перемикальних пристроїв.

ключові слова: модель надійності, динамічне дерево відмов, ковзне резервування, перемикальний пристрій.

\section{Introduction}

To increase the reliability of technical systems, structural redundancy is used. This redundancy is that redundant components are added to the structure of the system, which after the failure of the main components and subsequent switching take over the performance of their functions. One of the types of structural redundancy in practice is the sliding redundancy. Such redundancy is used if the system is made up of several identical subsystems, all of which must work simultaneously to make the system work. Sliding redundancy is that a redundant subsystem is added to the system, which can replace any basic subsystem. While all major subsystems are operational, the redundancy subsystem is in an unloaded state. If necessary, several reserve subsystems can be added to the structure of the system. The paper considers the simplest kind of redundancy, in which the system is composed of two main subsystems and one redundancy. When analyzing the reliability of systems with sliding redundancy, one of the principal factors is the consideration of the influence of switching devices. This influence consists in the appearance of errors of the first and second type. Under the error of the first type, we mean a false operation of the switching device. This means that the main subsystems are functional, but the switching de- vice decided that one of them is inoperable, and connected a redundancy. Under the second type of error, we understand the missed switching point of the switching device. This means that one of the main subsystems refused, but the switching device decided that such subsystem is operable and did not connect a redundancy subsystem. Both errors reduce the reliability of the system and cause underutilization of the resource. The described problem with switching devices is relevant for the design and operation of mechanical and electrical systems of responsible use.

This work is part of a series of publications devoted to the search for approaches to account for the influence of errors in switching devices for systems with different types of booking. In [1] it is described how to correctly take into account and estimate the influence of the switching device error of the system according to 2-of-3 scheme. This work is a continuation of this research, provided that the redundancy component is unloaded.

\section{The object of research and its technological audit}

The object of research is a non-renewable system with a single sliding redundancy. It consists of the same energy sources G1, G2 and G3 and the same switching devices S1 
and S2. Device S1 switches between sources G1 and G3, and device S2 - between sources G2 and G3 (Fig. 1).

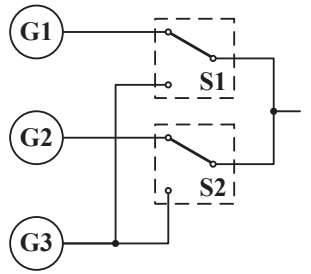

Fig. 1. Block diagram of the system

The system is designed to supply the consumer with energy that is connected to a common point connecting the outputs of the switching devices S1 and S2. The system is operable if at least two able-bodied sources are connected to the consumer. Let's consider the principle of the functioning of the system, provided that it is non-renewable and switching devices can't return to their original state. Let's believe that in the initial state all sources are operable. The switching device $\mathrm{S} 1$ connects the consumer to the source G1, and the device S2 - to the source G2. The source G3 is currently in a cold reserve. In the event of a failure of the source G1, the device S1 switches and connects the consumer to the source G3. In the event of a failure of the source G2, the device S2 switches and connects the consumer to the source G3. Immediately after connection, the source G3 goes into the loaded mode. In the event of failure of both sources G1 and G2, regardless of the state of the source G3, the system becomes inoperable.

A typical disadvantage of the system is that the switching devices S1 and S2 make errors that reduce its reliability. If the device $\mathrm{S} 1$ allows an error of the first type, then instead of the working source G1 it connects the source G3. If the device S1 tolerates an error of the second type, it does not connect the source G3 in place of the disabled source G1. If the device S2 admits a first-order error, then instead of the capable source $\mathrm{G} 2$, regardless of the state of the device S1, the source G3 is connected. If the device $\mathrm{S} 2$ tolerates an error of the second type, it does not connect the source G3 in place of the disabled source G2.

\section{The aim and objectives of research}

The aim of research is formalization and analysis of the effect of errors of the first and second type of switching device on the reliability characteristics of a non-renewable system with a single sliding redundancy.

To achieve this aim, it is necessary to solve the following tasks:

1. Mathematically describe the reliability of a system with sliding redundancy and switching devices based on a multi-terminal dynamic failure tree.

2. Construct a graph of states and transitions of the system and turn it into a Markov model designed to calculate the probability of failure-free operation of the system, taking into account the error parameters of the switching devices.

\section{Research of existing solutions of the problem}

In the research literature there are several approaches to the solution of this problem. The first approach is based on the application of mathematical simulation by the Monte Carlo method. To this end, in [2, 3], dynamic phenomena in the system were formalized by a tree of failures, and in [4] a binary choice diagram (Decision Binary Diagram). For this approach, the initial form of formalization isn't so important. The approach can be adequately applied to any probability distributions and various structural schemes of the system. The basic drawback of this approach is the distortion of simulation results by random fluctuations. The size of such fluctuations is so high that it is not possible to adequately reflect the influence of the error of the switching device on the reliability of the system.

The second approach is based on the application of Markov models. In [5] it is shown how, using the usual tree of failures, a Markov model is formed. Based on this model, the computation of integrated reliability indicators and this assessment causes the system's inoperability. The disadvantage of the work is the inability to describe the dynamic phenomena, if the usual tree of failures is used, and the cumbersomeness of the Markov models. In [6] it is shown how, using the logic conditions of blocks of the fault tree, describe the dynamic phenomena of load redistribution and form the corresponding Markov model. In [7], dynamic phenomena are formalized by blocks «PriorityAND», «Priority-OR» «PDEP», «SEQ» «SPARE». The authors paid attention to the technology of construction and the reduction of the Markov model on the basis of using its symmetry. The drawback of both works is the impossibility of mathematically describing the operation of the switching device. In [8] for the formalization of dynamic phenomena use «Functional Dependency Gate», «Spare Gate» and «Priority-AND Gate». In the failover tree of the entire system, dynamic failure sub-trees are selected for which multiple selection charts are generated. Based on such diagrams, create and compute the Markov model. The disadvantage of the approach remains the question of formalizing the description of a system with sliding redundancy. In addition, a separate analysis of the dynamic phenomena in such system will be more difficult than its immediate Markov analysis.

The third approach is based on the use of a set of heuristic methods that simplify or do not use Markov models. In [9], the reliability of the system is formalized by an ordinary tree of failures. To describe dynamic phenomena, the resulting tree is converted into a «Dynamic Uncertain Causality Graph». The resulting graph is calculated on the basis of algebraic methods. The disadvantage of the method is the impossibility of formalizing the whole spectrum of phenomena associated with the reliability of the switching device. In [10], dynamic phenomena are formalized using the single operator «FDEP», which is considered as a functional dependence. The failure tree of the system is analyzed from the point of view of the functioning of the system in various modes. For each mode, a combinatorial computation is performed based on the total probability formula. The results for individual mode calculations are reduced to a single number. The described method for simplifying the failure tree does not provide an adequate description of the influence of the errors of the switching device on the reliability of the system. In [11-13], the formalization of dynamic phenomena is performed on the basis of the operators «Cold Spare Gate» and «PriorityAND Gate». The authors propose to decompose these 
operators to ordinary OR and AND on the basis of integral expressions, and calculate the probabilistic indicators by the stochastic method. The method is based on permutations according to certain rules of units and zeros in the expression of probability, represented in the form of a binary number. The disadvantage of this approach is the difficulty in formalizing the reliability of a system with sliding redundancy and the further logic of the operation of the switching device.

\section{Methods of research}

At the first stage let's construct a tree of failures of the system, proceeding from the assumption that the switching devices are ideal, that is, they operate instantly and do not allow errors. At the second stage, let's consider the features of building a tree of failures, taking into account these errors.

The disability of the system with ideal switching devices is denoted by the «Top Event 1» block (Fig. 2).

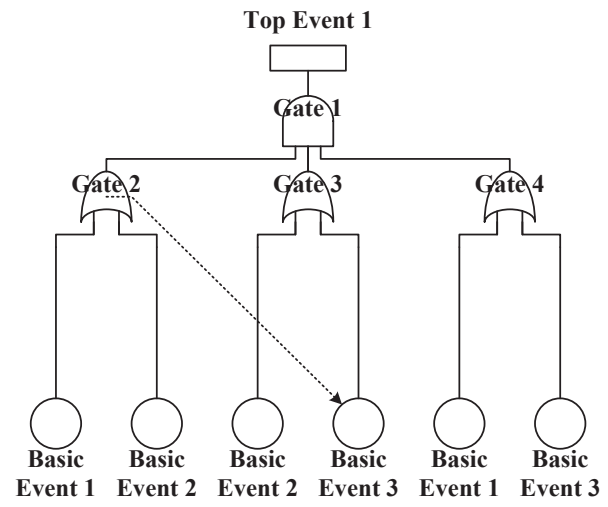

Fig. 2. Fault tree of the system with ideal switching devices

Such incapacity for work arises if the power to the consumer can't be supplied either by the main method or by two redundancy methods, described by the block «Gate 1», the type of which is set by logical operation AND. The main way is to not feed the consumer if there is no supply from at least one of the sources G1 or G2, described by the block «Gate 2», the type of which is set by the logical operation OR. The first redundancy method can't be powered by the consumer if there is no power from the source G2 or G3, as described by the block «Gate 3», which type is specified by the logical OR operation. And, the second redundancy method - if there is no power from the source G1 or G3, as described by the block «Gate 4», which type is specified by the logical operation OR. The reason for the lack of food from the source is its failure. Let's consider that the operating time to the failure of sources G1, G2 and G3 is distributed according to the exponential distribution with the parameters $\lambda_{1}, \lambda_{2}$ and $\lambda_{3}$.

A dynamic phenomenon occurs in the system, which consists in changing the intensity of the operating life of the redundancy source G3, depending on the state of the main sources G1 and G2. To describe this phenomenon in the block «Gate $2 »$, set the logical condition. If both generators G1 and G2 are operable, that is, the signal at the output of the block is FALSE, then the gain of the generator G3 is zero. If at least one of the generators G1 or G2 is disabled, that is, the signal at the output of the block is TRUE, then the gain of the generator G3 is set to $\lambda_{3}$.

To describe the inoperability of the system, taking into account the errors of the first and second types of switching devices, two phenomena should be taken into account in the model, namely, the unauthorized switching of contacts and the operating time to the failure of the control system of switching devices. In order to take into account the operating time of the switching device control system, the blocks «Top Event 2» and «Top Event 3» (Fig. 3) were added to the fault tree, that is, the fault tree is multi-terminal. The «Top Event 2» block indicates the disability of the control system of the S1 device, and the «Top Event 3» block indicates the disability of the S2 device control system. Since the control system of the switching device is, in terms of reliability, singlecomponent, the blocks «Top Event 2» and «Top Event 3» in the content correspond to the blocks «Basic Event 5» and «Basic Event 7 ». The operating time to failure of the control systems of devices S1 and S2 is distributed according to the exponential distribution with the parameters $\lambda_{5}$ and $\lambda_{7}$.

To take into account the unauthorized switching of device contacts to the fault tree, blocks «Basic Event 4» and «Basic Event 6» were added. The «Basic Event 4» block indicates the state of the contacts of the device S1, in particular, the connection of the source G1 is considered to be the position FALSE, and the source connection G3 - the position TRUE.

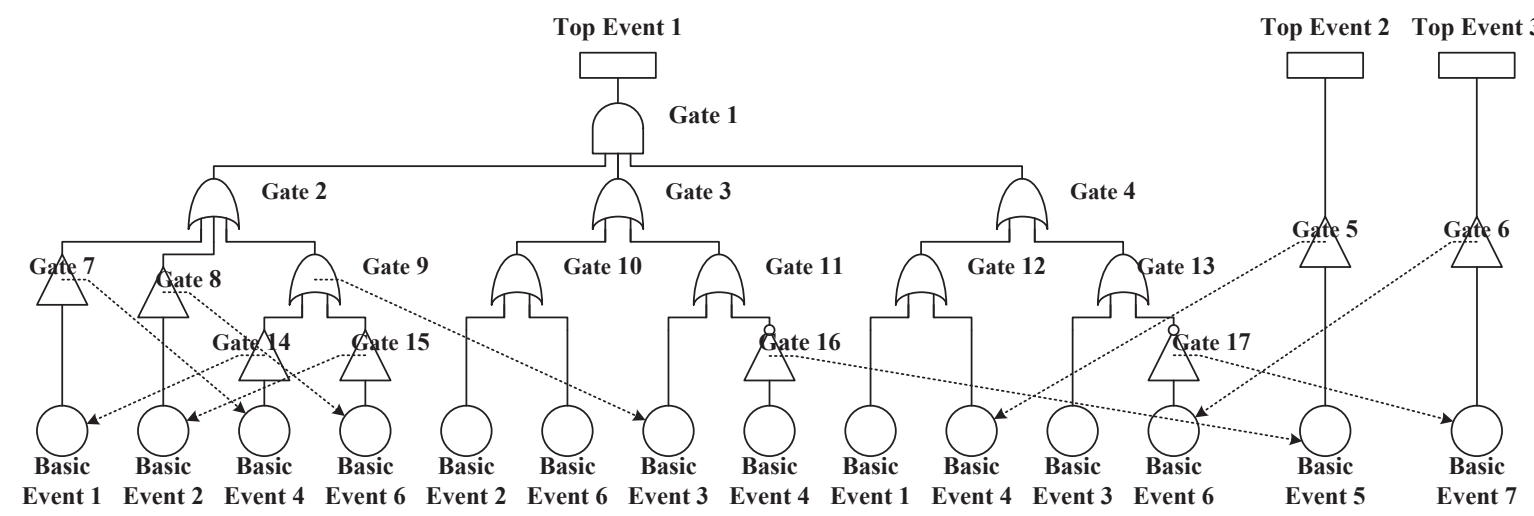

Fig. 3. Fault tree of the system taking into account the errors of the first and second type of switching devices 
The block «Basic Event 6» indicates the status of the contacts of the device S2, in particular, the connection of the source G2 is assumed to be the FALSE position, and the connection of the source G3 by the position TRUE. The probability of spontaneous switching of contacts of devices S1 and S2 is distributed according to the exponential distribution with the parameters $\lambda_{4}$ and $\lambda_{6}$.

The absence of power from the source G1 occurs if this source fails or the contact of the switching device S1 is in the TRUE position. This is described by the «Gate 7» and «Gate 12» blocks, the type of which is specified by the logical OR operation. In turn, the lack of power from the source G2 occurs if this source fails or the contact of the switching device S2 is in the TRUE position. This is described by the «Gate 8 » and «Gate 10» blocks, the type of which is specified by the logical OR operation. The absence of power from the source G3, occurs in two cases. First, such source failed or the contact of the switching device $\mathrm{S} 1$ is in the FALSE position. This is described by the «Gate 11» block, which type is specified by the logical OR operation. And, secondly, such source failed or the contact of the switching device S2 is in the FALSE position. This is described by the «Gate 13» block, whose type is specified by the logical OR operation. For the inversion of signals from the «Basic Event 4» and «Basic Event 6» blocks, the «Gate 16» and «Gate 17» blocks are used, the type of which is specified by the logical operation NOT.

In the system there are nine dynamic phenomena, which consist in changing the intensity of the operating time of the components and the switching intensity of the contacts, depending on the state of the other components.

The first phenomenon is the change in the load of the redundancy generator G3, depending on the state of the switching devices S1 and S2. For its description, let's add to the fault tree block «Gate 9» of type OR, in which set the logical condition. If both switching devices are in the FALSE state, then the gain of the generator G3 is zero, that is, the generator G3 is in an unloaded state. If at least one of the switches S1 or S2 has connected the generator $\mathrm{G} 3$, then its operating time is $\lambda_{4}$.

The second phenomenon consists in changing the switching intensity of the device S1 depending on the state of the source G1. For its description, let's add a block «Gate 7 » to the fault tree, in which specify a logical condition. If the source G1 is able to work, then the switching intensity of the device $\mathrm{S} 1$ is $l_{4}$. In this case, the process of spontaneous switching is the source of the error of the first type. If the source G1 is inoperable, then the switching intensity of the device $\mathrm{S} 1$ is increased by $\mathrm{k}$ times. In this case, the switching process ensures that the system leaves the inoperative state.

The third phenomenon consists in changing the switching intensity of the device S2 depending on the state of the source G2. In the failure tree, it is described similarly to the second dynamic phenomenon with the addition of the block Gate 8.

The fourth phenomenon consists in changing the intensity of the operating time of the source G1, depending on the state of the contacts of the switching device S1. For its description, let's add the block «Gate 14» to the fault tree, in which specify the logical condition. If the contacts of the switch S1 are in the FALSE position, then the operating time of the source G1 is $\lambda_{1}$. If the contacts of the switch S2 are in the TRUE position, then the operating time of the source G1 is 0 . The introduction of this phenomenon into the model simplifies further calculations.

The fifth phenomenon consists in changing the intensity of the operating time of the source G2, depending on the state of the contacts of the switching device S2. In the failure tree, it is described similarly to the fourth dynamic phenomenon with the addition of the block Gate 15.

The sixth phenomenon consists in changing the intensity of the operating time of the control system of the switching device S1, depending on the state of its contacts. To describe this phenomenon in the «Gate 16» block, set the logical condition. If the contacts of device S1 are in the FALSE position, then the operating time of the control system of this device is $\lambda_{5}$. If the contacts are in the TRUE position, then the running time is set to zero. The introduction of this phenomenon into the model simplifies further calculations.

The seventh phenomenon consists in changing the switching intensity of the device S1 depending on the state of its control system. To describe this phenomenon, let's add the «Gate 5» block to the fault tree, in which set the logical conditions. If the control system of the device S1 is operable, then the switching intensity of its contacts is $\lambda_{4}$. If the control system fails, then the switching intensity is set to zero. This means that after the failure of the source G1, the contacts will not be able to switch, which will cause a second type error.

The eighth phenomenon consists in changing the intensity of the operating time of the control system of the device S2, depending on the state of its contacts. In the failure tree it is described similarly to the sixth phenomenon using the «Gate 17» block and the parameter $\lambda_{7}$.

The ninth phenomenon consists in changing the switching intensity of the device S2 depending on the state of its control system. In the tree of failures, it is described similarly to the seventh phenomenon with the addition of the block «Gate 6».

\section{Research results}

6.1. Graph of states and transitions of the system. Based on the fault trees presented above, graphs of states and transitions for a system with ideal switching devices (Fig. 4, a) and for the system taking into account the errors of the first and second types of switching devices are constructed (Fig. 4, b).

In Fig. 4 working states are painted white, and disabled - gray. Circle 1 (Fig. 4, c) reflects the state of the system by the presence of consumer power; circle 2 (Fig. 4,c) - state of the control system of the switching device S1; about 3 (Fig. 4, c) - the state of the device control system S2. The solid arc 4 reflects the failure of the sources G1, G2 and G3; dashed arc 5 - switching of the contact of devices S1 and S2; dotted arc 6 - failure of the control system of devices S1 and S2. The graph for the first system (Fig. 4, $b$ ) contains 6 states, of which 3 are absorbing, and 6 are transitions. The graph for the second system (Fig. 4, b) contains 56 states, of which 11 are absorbing and 114 transitions. 

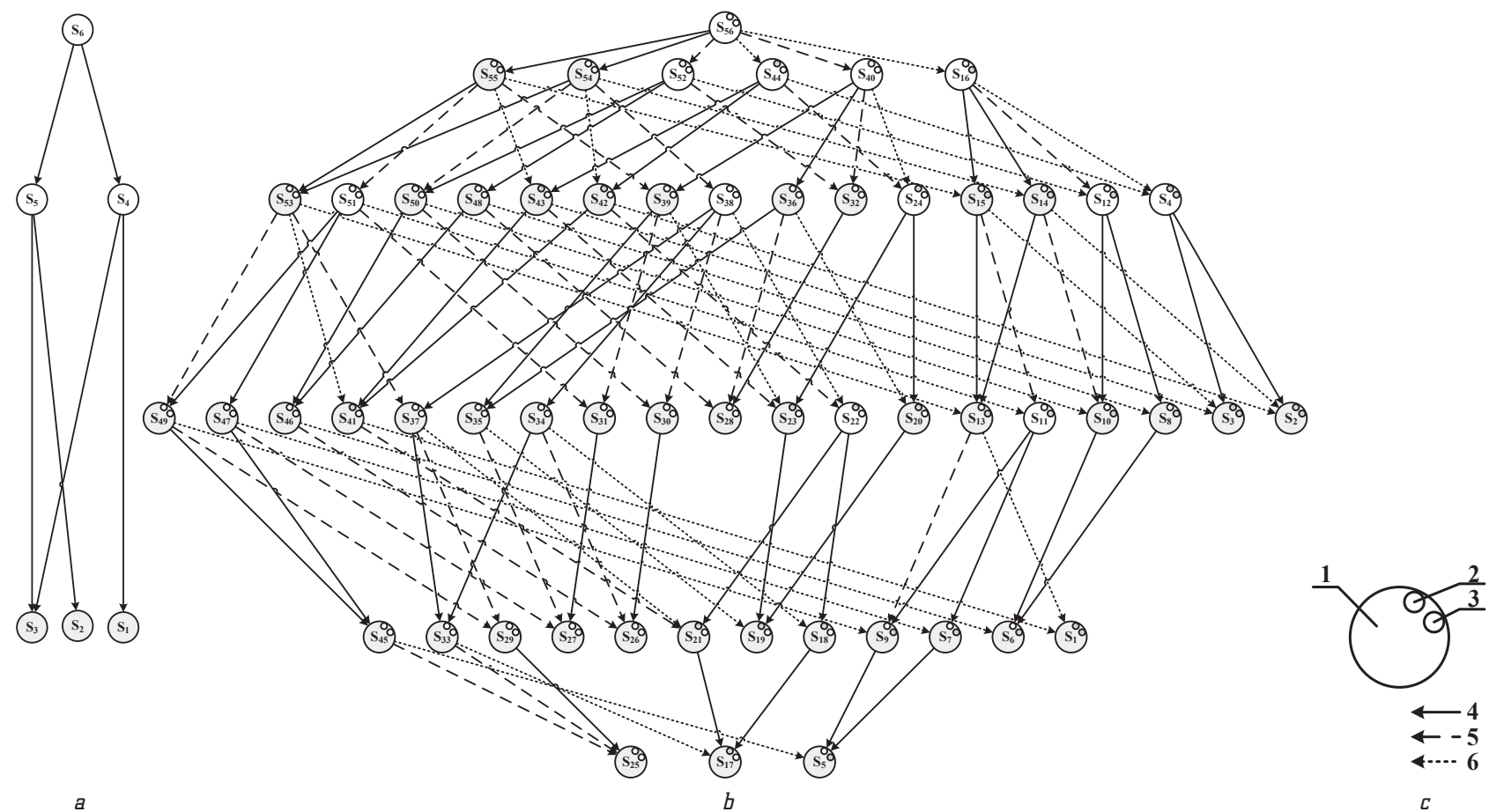

Fig. 4. State and transition diagram of the system:

$a$ - with ideal switching devices; $b$ - taking into account the errors of the first and second types of switching devices; $c$ - conventional symbols

6.2. Analysis of errors of the first and second type on the probability of failure-free operation of the system. Based on the graphs of states and transitions of the system, homogeneous Markov models are constructed using the calculated family of probability curves for the system's non-failure operation.

When analyzing the effect of errors of the first and second type, it is important not to have the absolute value of each of the parameters, but the ratio of the source parameters to the parameters of the switching devices, so it is expedient to perform calculations in relative units. For the base value, we take the failure rate of the source G1 $\lambda_{1}=1$. Since the sources G1, G2 and G3 are the same, therefore $\lambda_{1}=\lambda_{2}=\lambda_{3}=1$.

Let's assume that the ratio of the intensity of the unauthorized switching of the first device S1 $\lambda_{4}$ to the average switching time in the nominal mode of operation is $k_{1}=10,000$. The value of this ratio is inversely proportional to the switching inertia of the switching device and, in the extreme case, must go to infinity. Since the switching devices are the same, therefore $\lambda_{4}=\lambda_{6}, \lambda_{5}=\lambda_{7}$.

In Fig. 5, and a family of curves for the probability of failure-free operation of the system for different values of the parameters $\lambda_{4}=\lambda_{6}$ is given, which correspond to a first-type error, under the condition $\lambda_{5}=\lambda_{7}=1$. In particular, curve 1 corresponds to the value $\lambda_{4}=\lambda_{6}=0$ curve $2-$ $\lambda_{4}=\lambda_{6}=0.1 ;$ curve $3-\lambda_{4}=\lambda_{6}=0.5$; curve $4-\lambda_{4}=\lambda_{6}=1$; curve $5-\lambda_{4}=\lambda_{6}=2$ and curve $6-\lambda_{4}=\lambda_{6}=10$.

Fig. $5, b$ shows a family of curves for the probability of failure-free operation of the system for various values of the parameters $\lambda_{5}=\lambda_{7}$, which correspond to an error of the second type, under the condition $\lambda_{4}=\lambda_{6}=1$. In particular, curve 1 corresponds to the value $\lambda_{5}=\lambda_{7}=0$ curve $2-\lambda_{5}=\lambda_{7}=1$; curve $3-\lambda_{5}=\lambda_{7}=10$, curve $4-$ $\lambda_{5}=\lambda_{7}=100$ and curve $5-\lambda_{5}=\lambda_{7}=\mu$.
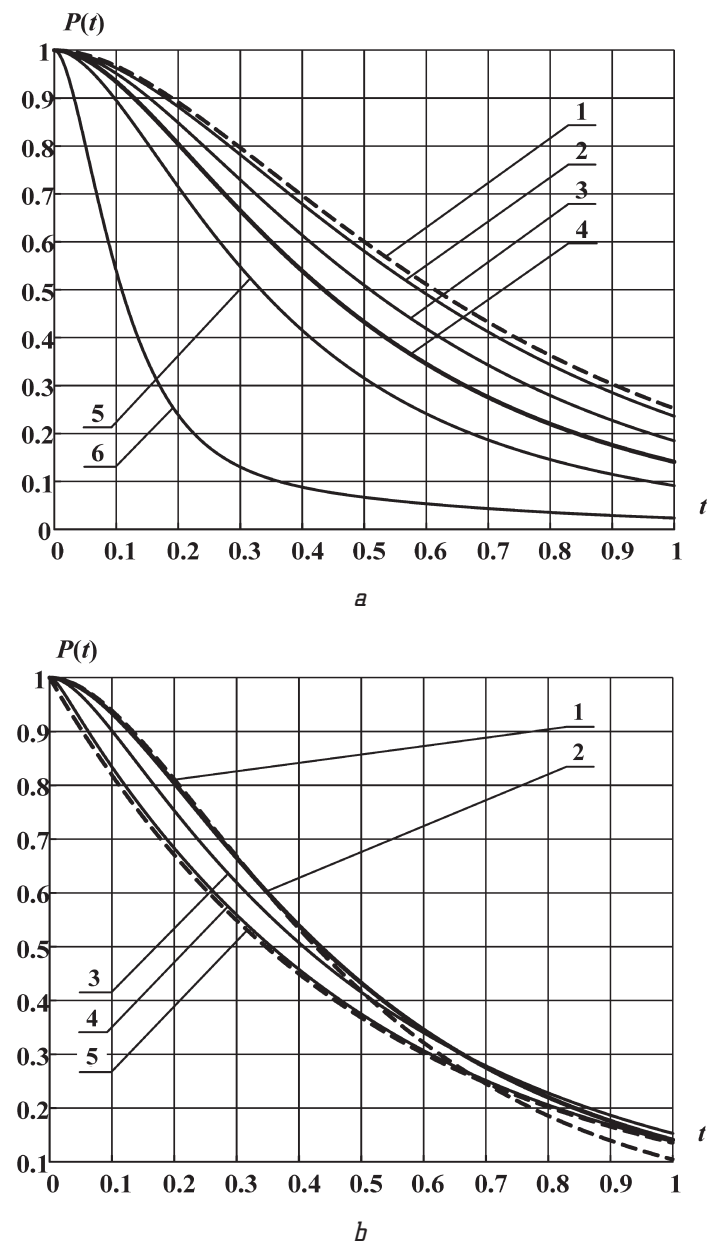

Fig. 5. A family of curves for the probability of failure-free operation of the system, which show the influence of the егror of the switching device: $a-$ of the first type; $b-$ of the second type 
For the purpose of comparing the results, curve 4 in Fig. 5, $a$, and curve 2 in Fig. 5, $b$, which are indicated by thickened lines, is the same characteristic, corresponds to the condition $\lambda_{4}=\lambda_{6}=1$ and $\lambda_{5}=\lambda_{7}=1$. Parameters $\lambda_{4}=\lambda_{6}$ and $\lambda_{5}=\lambda_{7}$ can take values in the range from 0 to $\infty$, where the value 0 corresponds to the absence of influence of the error, and the value of $\infty$ is the absolute influence of this error. In Fig. 5, and the curve corresponds to the condition $\lambda_{4}=\lambda_{6}=\mu$ is not shown, since the reliability in this case tends to 0 . This corresponds to the case when both switching devices are triggered at the initial moment, which immediately turns the system into an inoperable state.

As can be seen from the figures in Fig. 5 graphs, with a step-by-step increase in the parameters $\lambda_{4}=\lambda_{6}=\mu$, and $\lambda_{5}=\lambda_{7}$, the probability of failure-free operation of the system is reduced. On the curves in Fig. 5, $b$ constructed for the error of the second type, with a change in the parameters $\lambda_{5}=\lambda_{7}$ in the range from 0 to 1 , let's observe an increase in the influence of the second type error, which leads to an increase in system non-failure. As a result, we observe a phenomenon in which, for a time $t=1$, the reliability of a system in which an error of the second type is absent is lower in terms of the reliability of a system in which there is no redundancy at all. This phenomenon requires further investigation.

\section{SWOT analysis of research results}

Strengths. Accounting for the errors of switching devices in the analysis of the reliability of a non-renewable system with a single sliding redundancy contributes to the more efficient use of reserve components, increasing the probability of failure-free operation of the system and indirectly reducing the costs of eliminating emergencies.

Weaknesses. The use of multi-terminal tree failures with a large number of dynamic relationships and Markov analysis greatly complicates mathematical calculations, requires the involvement of a specialist in reliability. With an increase in the number of basic or reserve components, a model is developed that requires substantial refinement, starting with the stage of building the failure tree.

Opportunities. The obtained results will be used to develop a generalized methodology for constructing mathematical reliability models for various types of structural redundancy. A separate study requires a phenomenon in which the reliability of a system in which an error of the second type is absent is lower in terms of the reliability of the system in which there is no redundancy at all.

Threats. The reliability model constructed in the work, formed from the condition that the operating time of components to failure, as well as the flow of errors of the first and second type are distributed exponentially. If the actual distribution differs significantly from the exponential distribution, then the gain in accuracy can be leveled.

\section{Conclusions}

1. In the work, the dynamic fault tree of a non-renewable system with a single sliding redundancy and ideal switching devices was converted into a multi-terminal dynamic failure tree. Due to this, it was possible to introduce into the model nine dynamic phenomena of mutual influence of components and switches, in particular, such phenomena as unauthorized switching of contacts and the operating time to the failure of the control system of switching devices. As a result, the original dynamic fault tree containing 1 block «Top Event», 4 blocks «Gate» and 6 blocks «Basic Event» complicated up to 3 blocks «Top Event», 17 blocks «Gate» and 14 blocks «Basic Event». However, this made it possible to take into account the influence of the errors of switching devices on the probability of failure-free operation of the system.

2. Due to the replacement of ideal switching devices with switching devices that tolerate errors, the number of system states for the state graph and transitions has increased from 6 to 56, and the number of transitions has increased from 6 to 114. This allow to take into account the states in which the system as a whole and state of the control system of individual switching devices. In the Markov model of the system, the parameters of the switching devices are added, such as the intensity of the false operation of the switching device, corresponds to the error of the first type, and the intensity of the operating time of the control system of the switching device, which corresponds to a second-type error. It is established that with a step-by-step increase in the switching intensity of the switching devices' contacts and the intensity of the operating time of the switching device control system, the probability of failure-free operation of the system is reduced.

\section{References}

1. Stefanovych T., Shcherbovskykh S. Taking into account type I and II errors of switching device for system with 2-out-of-3 redundancy // Information extraction and processing. 2017. Vol. 45, Issue 121. P. 56-62.

2. Zhang P., Chan K. W. Reliability Evaluation of Phasor Measurement Unit Using Monte Carlo Dynamic Fault Tree Method // IEEE Transactions on Smart Grid. 2012. Vol. 3, Issue 3. P. 1235-1243. doi: http://doi.org/10.1109/tsg.2011.2180937

3. Shcherbovskykh S., Lozynsky O., Marushchak Y. Failure Intensity determination for system with standby doubling // Przeglad Elektrotechniczny. 2011. Vol. 87, Issue 5. P. 160-162.

4. Lin Y.-H., Li Y.-F., Zio E. A Reliability Assessment Framework for Systems With Degradation Dependency by Combining Binary Decision Diagrams and Monte Carlo Simulation // IEEE Transactions on Systems, Man, and Cybernetics: Systems. 2016. Vol. 46, Issue 11. P. 1556-1564. doi: http://doi.org/ 10.1109 /tsmc. 2015.2500020

5. Development of a reliability model to analyse the causes of a poultry module failure / Shcherbovskykh S. et. al. // Eastern-European Journal of Enterprise Technologies. 2016. Vol. 4, Issue 3 (82). P. 4-9. doi: http://doi.org/10.15587/1729-4061.2016.73354

6. Shcherbovskykh S., Stefanovych T. Reliability model developing for protective fittings taking into account load-sharing effect // Eastern-European Journal of Enterprise Technologies. 2015. Vol. 1, Issue 3 (73). P. 37-44. doi: http://doi.org/ 10.15587/1729-4061.2015.35951

7. Volk M., Junges S., Katoen J.-P. Fast Dynamic Fault Tree Analysis by Model Checking Techniques // IEEE Transactions on Industrial Informatics. 2018. Vol. 14, Issue 1. P. 370-379. doi: http://doi.org/10.1109/tii.2017.2710316

8. Yuchang M. A Multiple-Valued Decision-Diagram-Based Approach to Solve Dynamic Fault Trees // IEEE Transactions on Reliability. 2014. Vol. 63, Issue 1. P. 81-93. doi: http:// doi.org/10.1109/tr.2014.2299674

9. Zhou Z., Zhang Q. Model Event/Fault Trees With Dynamic Uncertain Causality Graph for Better Probabilistic Safety Assessment // IEEE Transactions on Reliability. 2017. Vol. 66, Issue 1. P. 178-188. doi: http://doi.org/10.1109/tr.2017.2647845

10. Xing L., Morrissette B. A., Dugan J. B. Combinatorial Reliability Analysis of Imperfect Coverage Systems Subject to Functional Dependence // IEEE Transactions on Reliability. 2014. Vol. 63, Issue 1. P. 367-382. doi: http://doi.org/10.1109/tr.2014.2299431

11. Stochastic Approach for the Analysis of Dynamic Fault Trees With Spare Gates Under Probabilistic Common Cause Failures / Zhu P. et. al. // IEEE Transactions on Reliability. 2015. Vol. 64, Issue 3. P. 878-892. doi: http://doi.org/10.1109/tr.2015.2419214 
12. A Stochastic Approach for the Analysis of Fault Trees With Priority AND Gates / Zhu P. et. al. // IEEE Transactions on Reliability. 2014. Vol. 63, Issue 2. P. 480-494. doi: http:// doi.org/10.1109/tr.2014.2313796

13. Approximate reliability of multi-state two-terminal networks by stochastic analysis / Zhu P. et. al. // IET Networks. 2017. Vol. 6, Issue 5. P. 116-124. doi: http://doi.org/10.1049/iet-net. 2017.0033
Stefanozych Tetyana, PhD, Associate Professor, Department of Mechanical Engineering, Lviv Polytechnic National University, Ukraine, e-mail: tetyana.o.stefanozych@lpnu.ua, ORCID: http:// orcid.org/0000-0002-8577-4755

Shcherbovskykh Serhiy, Doctor of Technical Sciences, Senior Researcher, Department of Computer-Aided Design, Lviv Polytechnic National University, Ukraine, e-mail: shcherbov@gmail.com, ORCID http://orcid.org/0000-0001-8535-733X

\section{Radzinskaya $\mathbf{Y}$, DETERMINATION OF INVESTMENT Korniiets A. ACCURACY AND FORMATION OF INFORMATION SUPPLY OF GEOECOLOGICAL MONITORING OF USE OF LAND}

Об’єктом дослідження є технологія визначення інвестиційної привабливості та формування інформачійного забезпечення геоекологічного моніторингу використання земель. Однією з найбільших проблем в сучасних підходах до визначення інвестиційної привабливості та геоекологічного стану використання земель є складність існуючих підходів та відсутність інформаційного забезпечення.

Розроблено методи до оиінки інвестииійної привабливості та геоекологічного стану використання земель. Ці методи дають можливість розробити заходи до комплексного зростання інвестииійної привабливості та визначення геоекологічного стану земель для формування методичних рекомендацій щодо підвищення ефективності використання земель. Запропоновані підходи мають аналітичний характер та базуються на методі аналізу ієрархій, результатах кореляційно-регресійного аналізу. На відміну від існуючих, вони дали змогу сформувати системне середовище для кількісної оцінки геоекологічного стану та використання земель.

В ході досліджень використовувалися просторовий, багатофакторний, рейтинговий та економічний підходи. Виявлено, що вказані підходи не мають чіткої послідовності та не в повній мірі визначають сучасні аспекти використання земель.

За розробленими методами до оцінки інвестииійної привабливості та геоекологічного стану використання земель запропоновано комплексний підхід. Він базується на результатах математичного моделювання та дає можливість отримати інтегральну оцінку геоекологічного стану використання земель.

Завдяки цьому дані розробки забезпечать оиінку земель та прийняття рімень з боку заиікавлених осіб на місцевому, регіональному та державному рівнях. Розроблений інтегральний критерій дозволить підвищити рівень використання земель та забезпечить їх комплексну оцінку. Запропоновані рекомендації дадуть можливість чітко та обгрунтовано вплинути на рівень використання земель, та своєчасно його врегулювати. У порівнянні з відомими підходами, розроблений має комплексний характер та базується на послідовних етапах аналітичних розрахунків. Це забезпечує точність оцінки та виключає вплив об'єктивних факторів при визначенні інвестиційної привабливості та геоекологічного стану використання земель.

Ключові слова: інвестииійна привабливість земель, геоекологічний моніторинг, інформачійне забезпечення, використання земель.

\section{Introduction}

Creation of a favorable investment climate and geoecological state in the land sector directly determines the further development of both cities and regions and the country as a whole. The processes of development of cities and regions, first of all, are stipulated by the volume and rates of growth of investments in their lands, will change their structure and qualitative characteristics. Along with this, in most regions of Ukraine there are problems in balancing the environmental support for land use. Deepening of negative processes external and internal factors:

- degradation of natural ecosystems;

- loss of biodiversity;
- increase in the incidence of the population;

- global climate change;

- anthropogenic load on the natural environment;

- erosion;

- pollution;

- moistening and bogging of soils;

- decrease in efficiency of land use.

To solve the presented problems, geoecological monitoring systems are used, which are formed on the basis of information support for increasing the efficiency of land use, taking into account the influence of environmental factors. But, in most cases, the set of factors that directly shapes the investment attractiveness of the land and form the information support for geoecological monitoring of 